\title{
Assembly of Oligoglycine Layers on Mica Surface*
}

\author{
Svetlana V. Tsygankova ${ }^{1}$, Alexander A. Chinarev ${ }^{1}$, Alexander B. Tuzikov ${ }^{1}$, Ilya S. Zaitsev ${ }^{1}$, \\ Nikolai Severin ${ }^{2}$, Alexey A. Kalachev ${ }^{3}$, Jurgen P. Rabe ${ }^{2}$, Nicolai V. Bovin ${ }^{1^{*}}$
}

${ }^{1}$ Shemyakin-Ovchinnikov Institute of Bioorganic Chemistry, Moscow, Russia; ${ }^{2}$ Department of Physics, Humboldt University Berlin, Berlin, Germany; ${ }^{3}$ Plasmachem GmbH, Berlin, Germany.

Email: bovin@carb.ibch.ru

Received October $7^{\text {th }}, 2010$; revised November $10^{\text {th }}, 2010$; accepted December $20^{\text {th }}, 2010$.

\begin{abstract}
Assembly of $\left[\mathrm{Gly}_{7}-\mathrm{NHCH}_{2}\right]_{4} \mathrm{C}$, $\left[\mathrm{Gly}_{7}-\mathrm{NHCH}_{2}\right]_{3} \mathrm{C} \mathrm{CH}_{3}$ and $\left[\mathrm{Gly}_{4} \mathrm{NH}\left(\mathrm{CH}_{2}\right)_{5}{ }^{-}\right]_{2}$ peptides on mica surface in aqueous solution was studied. The peptides are capable of forming atomically smooth (2.65-4.3 $\mathrm{nm}$ in height) layers assembled as polyglycine II. Monomers in the layers are situated normally to the surface. Formation of analogous flat $2 D$ structures also takes place in solution but much more slowly than on mica surface, i.e. negatively charged surface plays an active role promoting the assembly.
\end{abstract}

Keywords: Self-Assembling, Oligoglycine, Scanning Force Microscopy, Monolayers

\section{Introduction}

Self-assembly of small molecules on solid surface is an attractive way for fabrication of advanced materials and nano-devices [1]. Basically, self-assembled monolayers (SAMs) constructed on gold from functionalized long-chain hydrocarbon thiols [2] are used for this purpose. Such SAMs, held primarily due to Van der Waals interaction, are rather soft architectures precisely reproducing imperfect curvature of the surface-template. In contrast, peptides are capable of forming rigid architectures due to multiple and highly narrowed hydrogen bonds [3]. This property is intrinsic i.e. generally it does not depend on the template. In polyglycine II structure, parallel peptide chains are arranged as $3_{1}$ helix forming a net of hydrogen bonds (all $\mathrm{CO}$ and $\mathrm{NH}$ groups are involved) [4-6]; this package is rigid and thus especially attractive for design of new flat layers and for smoothening of other rough surfaces. Canonical polyglycine II is formed by a long-chain polymer $\mathrm{Gly}_{\mathrm{n}}$ in a solid phase [4]; earlier, we have demonstrated that short oligoglycines with $\mathrm{n}=7$ are capable of forming the polyglycine II architecture if four chains are organized in a star-like manner [6]. Such symmetrical tetraantennary peptide $\left[\mathrm{Gly}_{7}-\mathrm{NHCH}_{2}\right]_{4} \mathrm{C}$ forms platelet-like 2D supramolecular assemblies (hereinafter referred as tectomers), which are proved to be stable not only in solid phase but also in aqueous solutions. In the both cases Raman spectra of

\footnotetext{
* The work was supported by the Program "Molecular and cell biology", from the Presidium of the Russian Academy of Sciences.
}

tectomers have a band pattern consistent to that of crystalline polyglycine II. We analyzed conceivable ways of $\left[\mathrm{Gly}_{7}-\mathrm{NHCH}_{2}\right]_{4} \mathrm{C}$ packaging in tectomers and choose the model, in which $\left[\mathrm{Gly}_{7}-\mathrm{NHCH}_{2}\right]_{4} \mathrm{C}$ monomers with paired antennae in polyglycine II conformation are situated normally to the tectomer plane. Thickness of this model structure is in the best agreement to thickness of tectomers measured by scanning force microscopy (SFM), 4.5 $\mathrm{nm}$ [6]. Later we showed that tectomers can be formed on a surface more readily than in solution volume, particularly on mica due to the opposite charges of terminal $\mathrm{NH}_{2}$ groups and mica surface [7]. The current paper describes the assembly of tetra-, tri-, and biantennary oligoglycine peptides (Scheme 1) on mica surface more closely and demonstrates that the assembly leads to atomically smooth and durable mono- or bi-layers (Scheme 2). Also we describe the application of scanning force microscopy for investigation of surface-promoted assembling of the antennary designed oligoglycines. Tectomers are attractive material for nanotechnologies, because they can serve as a platform for fabrication of nano devices, as well as for smoothing, strengthening, and functionalization of rough surfaces, and for encapsulation of micro-objects [8].

\section{Experimental}

Peptides [ $\left.\mathrm{Gly}_{7}-\mathrm{NHCH}_{2}-\right]_{4} \mathrm{C}$, $\left[\mathrm{Gly}_{7}-\mathrm{NHCH}_{2}-\right]_{3} \mathrm{CCH}_{3}$, and $\left[\mathrm{Gly}_{4}-\mathrm{NH}\left(\mathrm{CH}_{2}\right)_{5}{ }^{-}\right]_{2}$ (Scheme 1) were synthesized by activated esters method in solution, by stepwise elongation 


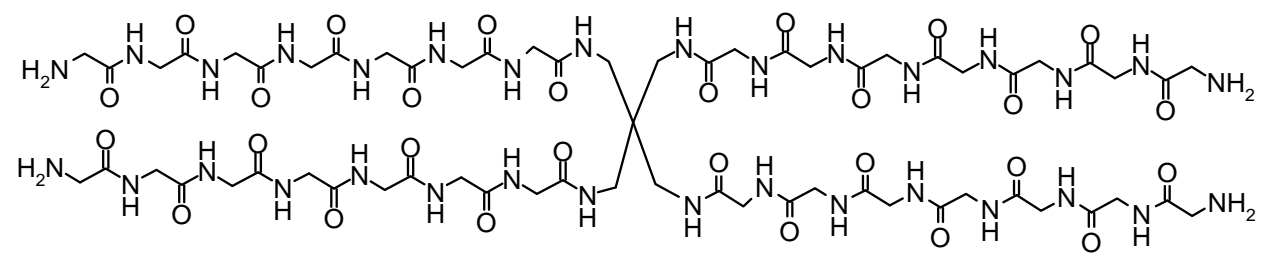

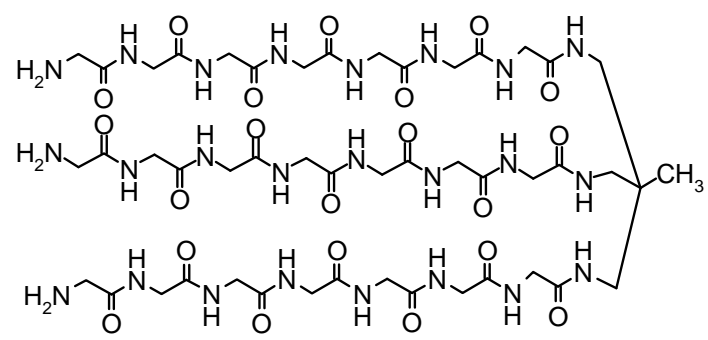<smiles>NCC(=O)NCC(=O)NCC(=O)NCC(=O)NCCCCCCCCCCNC(=O)CNC(=O)CNC(=O)CNC(=O)CN</smiles>

Scheme 1. Structures of bi-, tri- and tetraantennary oligoglycines.

(a)

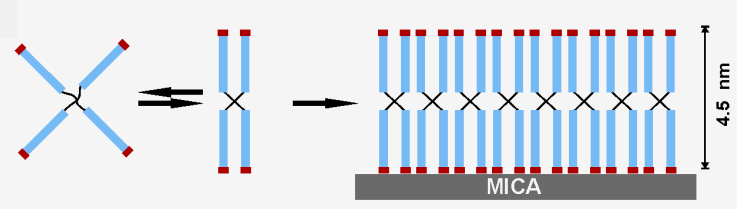

(b)

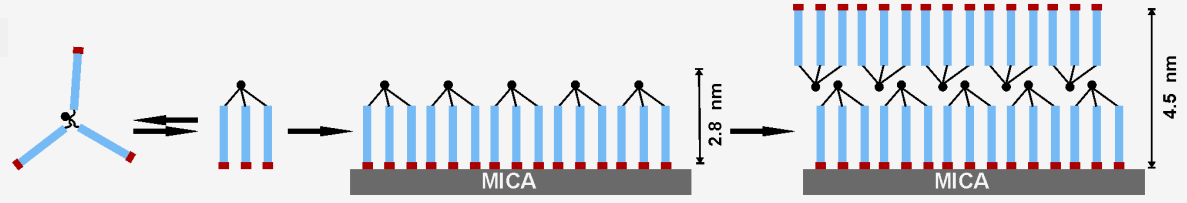

(c)

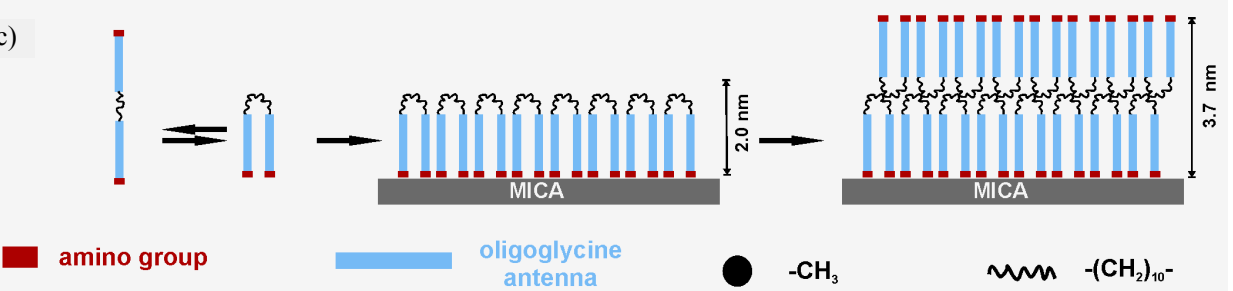

Scheme 2. Association of oligoglycines on mica surface. (a) The tetraantennary peptide form monolayer (" $2+2$ " packaging the monomer); (b) The triantennary peptide form mono- or bilayer ("3+0" packaging); (c) Biantennary molecules capable of forming mono- or bilayer (" $2+0$ " packaging). To form durable layers with polyglycine II structure, that stabilized by extensive network of H-bonds, the antennae of peptide molecules should have strict parallel orientation regarding each other, and thus should be normally oriented toward surface. Obviously, the peptide molecules should be directed to mica surface having negative zeta-potential by their amino groups, which may be positively charged; the suggested conformations of the peptides allow maximum cooperation upon interaction with mica.

of the chain by one or two glycine residues [6,9], and stored as $\mathrm{HCl}$ or $\mathrm{CF}_{3} \mathrm{COOH}$ salts. SFM images were recorded using a Nanoscope IIIa (Digital Instrument Inc., $\mathrm{CA})$ in air in tapping mode using microcantilevers with a typical resonance frequency $300 \mathrm{kHz}$ and spring constant $42 \mathrm{~N} / \mathrm{m}$, and in aqueous solutions in contact mode using $\mathrm{Si}_{3} \mathrm{~N}_{4}$ cantilevers with force constants $0.06 \mathrm{~N} / \mathrm{m}, 0.12$ $\mathrm{N} / \mathrm{m}, 0.32 \mathrm{~N} / \mathrm{m}$. 
The samples for the investigation in air were prepared as followed. Solution of $\mathrm{NaHCO}_{3}$ or $\mathrm{Na}_{2} \mathrm{CO}_{3}(0.1 \mathrm{M})$ was added to the peptide salt solution, thoroughly mixed and left to stay for 0-120 min. The mixture was placed on freshly cleaved mica and was incubated $(10 \mathrm{sec}-10 \mathrm{~min})$ at room temperature and normal pressure. The solution was removed from mica surface by spin coating.

For SFM experiments in aqueous solution freshly cleaved mica was placed to liquid cell followed by addition of water. Solution of $\mathrm{NaHCO}_{3}$ or $\mathrm{Na}_{2} \mathrm{CO}_{3}(0.1 \mathrm{M})$ was added to peptide salt solution $(0.1$ or $1 \mathrm{mg} / \mathrm{ml})$, thoroughly mixed for $10 \mathrm{sec}$ and immediately placed to the cell.

The obtained images were filtered with a flatten filter from Nanoscope III software.

\section{Results and Discussion}

Protonated forms of oligoglycines (Scheme 1) are incapable of self assembling due to the charge on the amino group, thus they exist in solution as monomers [6]. To initiate the assembling, an equivalent amount of base is added to aqueous solution of peptide salt. As this takes place the peptides adopt polyglycine II conformation (Raman spectroscopy, data not shown) gradually evolving from solution into separate phase.

Thus, we can speculate that the peptide layers assembled on mica would be 2D crystals of polyglycine II. Analyzing possible ways of the peptides packing into such crystalline layers we have fixed our attention on the variants presented in Scheme 2. Thus, for the tetraantennary peptide, " $2+2$ " packaging, in which two coplanar pairs of peptide antennae are oppositely directed, seems to be favorable as also is for solution-formed tectomer platelets studied earlier [6]. The triantennary molecule are presumably packed in tectomer layer as a trident (" $3+0$ " packaging). As regards the biantennary peptide, we suggest " $2+0$ " shape of its molecules within layer; molecular dynamic simulations of the peptide adsorption on mica confirms this assumption [7]. The SFM results obtained for each of the three peptides supports our proposal, and considered below.

\subsection{Tetraantennary Oligoglycine $\left[\mathrm{Gly}_{7}-\mathrm{NHCH}_{2}-\right]_{4} \mathrm{C}$}

Earlier we unambiguously showed, that platelet-like tectomers with polyglycine II structure were formed in solution, and the assembling takes a few hours [6]. Indeed, aqueous solutions with the deprotonated form of $\left[\mathrm{Gly}_{7}-\mathrm{NHCH}_{2}-\right]_{4} \mathrm{C}$ were allowed to stay for $\sim 60-120 \mathrm{~min}$ before the tectomers visualized by STM of the samples on of mica or graphite prepared from aliquots taken from the solutions, i.e. the tectomers were already formed be- fore application onto support surface. These observations were confirmed by light scattering, which also showed that spontaneous assembly of tectomer (in absence of mica) proceeded slowly, tectomers reached maximal sizes in about 1-2 $\mathrm{h}$ range, and then their precipitation from solution is started. Other conditions were used in this study, namely, the solution of the peptide was applied onto the mica surface immediately after adding base. It can be seen on Figure 1 that tectomer formation proceeds on mica surface much faster, over several minutes. Small islets are formed at first followed by gradual increase in lateral dimensions and complete uniform covering of the surface (layer $\mathrm{T}_{1}$ ); the layer roughness does not exceed $0.2 \mathrm{~nm}$. Sporadic appearing of the second layer, $\mathrm{T}_{2}$, (Figure 1b) is observed before the complete formation of the first one; the effect is more pronounced at higher concentrations of the peptide solutions (data not shown).

The thickness of the layer, about $4.3 \mathrm{~nm}$, corresponded to the length of the $\left[\mathrm{Gly}_{7}-\mathrm{NHCH}_{2}-\right]_{4} \mathrm{C}$ molecule in " $2+2$ " conformation; this also correlating well with the data obtained before for platelet-like tectomer formed in solution [6]. Morphological similarity between platelet-like tectomers and tectomer islets on mica may point that the both types of objects has the same nature, i.e. they are 2D crystals of polyglycine II. Notworphy, angles between tectomer edges are close to $120^{\circ}$ (Figures $\mathbf{1}(\mathbf{a}, \mathbf{b})$ ), which justifies their polyglycine II structure. The same is fair for the monolayer tectomer. Interestingly, the layer assembly proceeded not evenly but with acceleration.

Contact mode scanning of $1000 \times 1000 \mathrm{~nm}$ region of the already formed layer led to its power-driven destruction (Figure 2), however during five minutes the layer become restored due to peptides molecules being in excess in solution. By this example we can suggest that mica surface does not merely promote the assembly of oligoglycine peptides but also takes part in restoration of the tectomer layer.

Similar results were obtained when scanned in air in tapping mode (Figure 3). Thus, formation of islet type tectomer monolayer with the same height $4.3 \mathrm{~nm}$, as in case of the measurement in the liquid cell, took place. However, here, continuous peptide layer on mica was not formed; moreover, often the second, the third and etc. layers were simultaneously appeared. Planar size of the tectomer islets reaches several micrometers. Even though the time of exposure of the peptide solution at mica when scanned in air was relatively high ( $20 \mathrm{~min})$, it was still less than time required for the tectomer formation without mica ( $\sim 60 \mathrm{~min})$. Thus we concluded that peptide assembling proceeded rather on surface than in solution. However, a scenario when small primary (still easily 


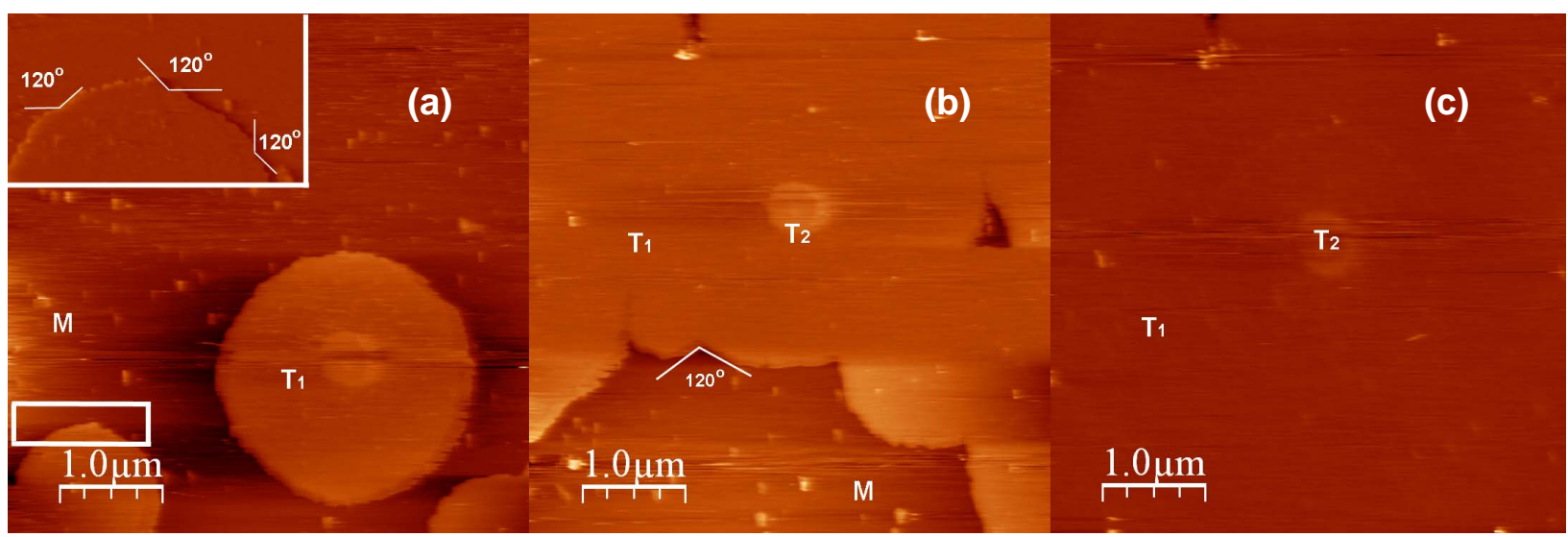

Figure 1. Growth of the tetraantennary peptide on mica surface; SFM contact mode in liquid cell. $T_{1}$, the first tectomer layer; $T_{2}$, the second tectomer layer; $M$, uncovered mica regions. (a), 2 min after starting the experiment; (b), 3 min; (c), 4 min.

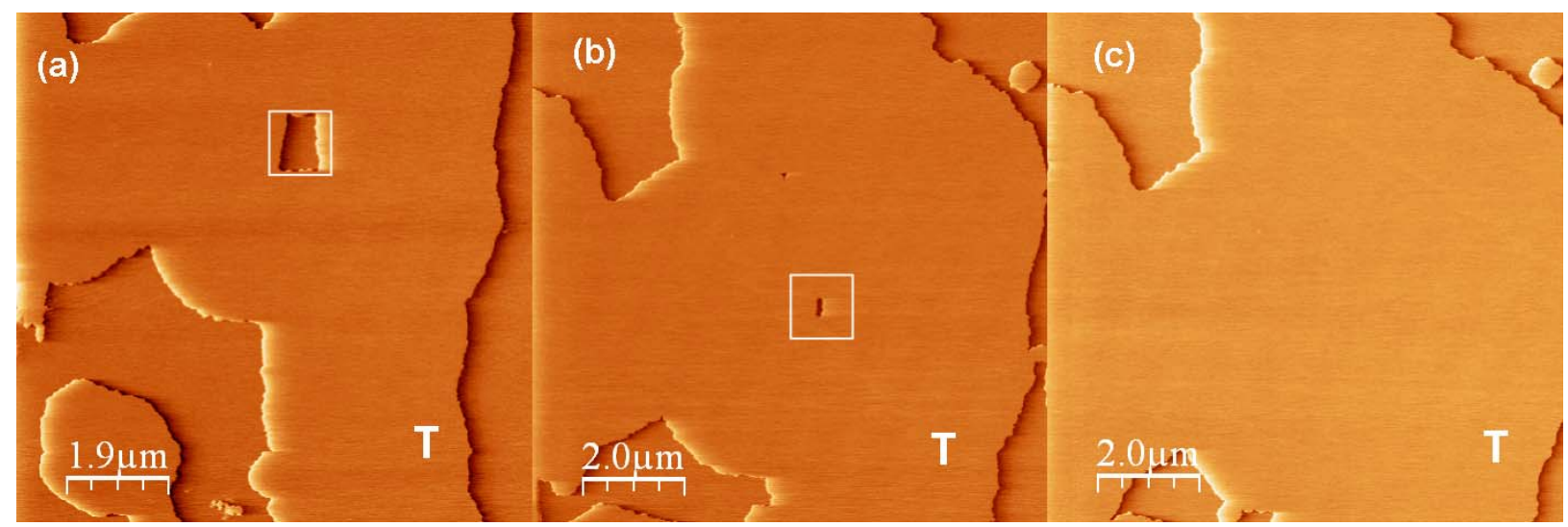

Figure 2. Destruction and restoring of the tectomer layer formed from $\left[\mathrm{Gly}_{7}-\mathrm{NHCH}_{2}\right]_{4} \mathrm{C}$; SFM contact mode in liquid cell. T, tectomer layer. (a) Partial destruction of the tectomer during the scanning of a region with the surface $1 \mu \mathrm{m}^{2}$ (square frame); (b) Partial restoring of the damaged layer; (c) The layer is completely restored $5 \mathrm{~min}$ after its destruction.
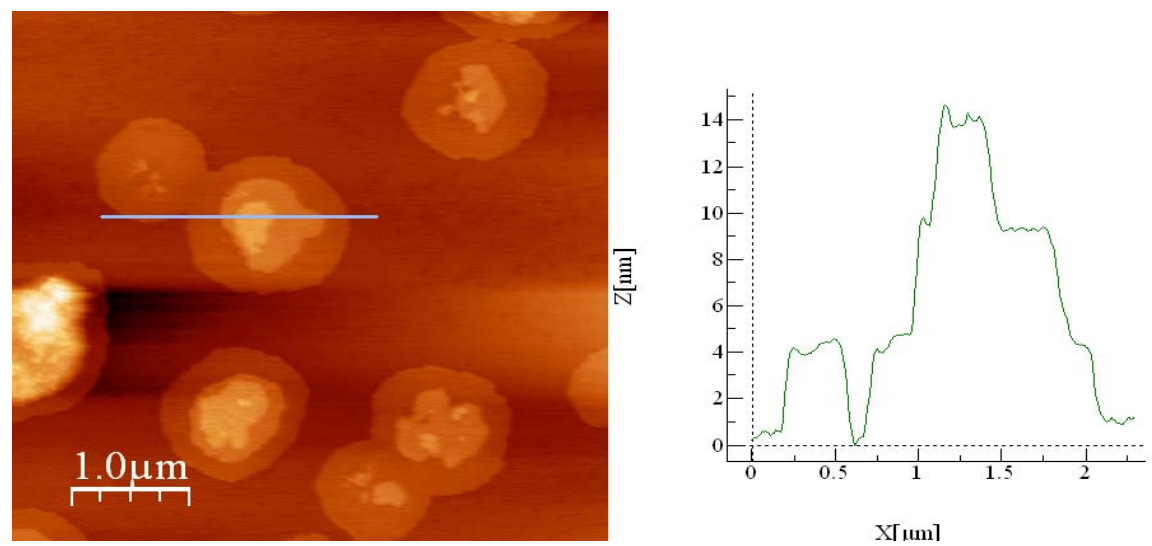

Figure 3. Assembling of the tetraantennary peptide on mica; SFM taping mode in air. Thickness of the primary, secondary and etc. tectomer layers is $4.3 \mathrm{~nm}$.

diffusing) germs are formed in solution first followed by their adsorption on the surface and final rapid overgrowing of the uncovered regions cannot be completely ex- cluded. Certainly, if the exposure time is over $60 \mathrm{~min}$ the assembling takes place both in solution and on mica surface. 


\subsection{Triantennary Oligoglycine $\left[\mathrm{Gly}_{7}-\mathrm{NHCH}_{2}-\right]_{3} \mathrm{CCH}_{3}$}

In contrast to the tetraantennary analog, we failed to observe growth dynamics of the triantennary peptide layer on mica surface (contact mode, liquid cell). Already in the initial experiments (the exposure time $2 \mathrm{~min}$ ) the surface was completely covered with the peptide layer. Moreover, the exhausting formation of the second layer with the thickness of $2.8 \mathrm{~nm}$ proceeded for five minutes. Such a drastic difference in the assembly of the tetra- and triantennary peptides can be explained by the difference of their packaging in tectomer layers. According to the layer thickness of $2.8 \mathrm{~nm}$, triantennary peptide is packaged in tectomer as a trident (" $3+0$ " conformation, Scheme 2b). Thus, three amino groups per peptide molecule contact the mica surface. Tetraantennary peptide assembled in monolayer in " $2+2$ " conformation, i.e. only two amino groups per molecule appear in contact with mica surface. This leads to more quick assembling of the tectomer monolayer by the triantennary molecules. In the latter case the outer interface of the formed monolayer is settled with hydrophobic methyl groups, which promotes more slow assembly of the secondary layer, in "head to head" manner. As the result, like in case of tetraantennary peptide the final surface is settled with amino groups, but the tectomer is bilayered here. The adherence of methyl group-tethered layers to each other (Scheme 2b) should be low. Indirect prove: the second layer has not been formed in the region where continuous scanning was carried out (Figure 4).

At the same time, the second layer can be formed in the regions where the scanning was not carried out. Peeling of a large region of the second layer took place sporadically when scanning (Figure 5) resulting in ex- posure of atomically smooth hydrophobic surface. It should be noted that edge of shear and angles of $120^{\circ}$ correspond to crystalline polyglycine II package $[4,5]$.

The triantennary peptide covers the whole of the mica surface, no islet-like structures were found in contrast to the tetraantennary; the observed height of $2.8 \mathrm{~nm}$ corresponding to " $3+0$ " conformation monolayer (in air scanning, data not shown).

\subsection{Biantennary Oligoglycine $\left[\mathrm{Gly}_{4}-\mathrm{NH}\left(\mathrm{CH}_{2}\right)_{5}-\right]_{2}$}

Already at the end of the second scanning, i.e. in 2 min, the surface was uniformly covered with the even defect-free tectomer layer (Figure 6). The layer height observed in liquid cell was $2.65 \mathrm{~nm}$. This may be explained with the model of the biantennary peptide in " $2+0$ " conformation, capable of bilayer formation (Scheme 2c). As in the case with the triantennary molecules, the primary layer is assembled directly on mica (expected thickness $2.0 \mathrm{~nm}$ ), and on its outer interface the secondary layer is formed at due to hydrophobic interactions between hydrophobic - $\left(\mathrm{CH}_{2}\right)_{10^{-}}$moieties. Noteworthy, molecular dynamic simulation of the peptide behavior in adsorption layer on mica confirms possibility of polyglycine II structure formation by the biantennary peptide in " $2+0$ " conformation; the calculated thickness of monolayer was close to $2.0 \mathrm{~nm}$ [7]. In liquid cell experiments the secondary layer was not observed, believed to be easily scraped off by cantilever.

Also we measured the layer thickness of $3.7 \mathrm{~nm}$ (in air experiments, tapping mode), which strictly corresponds to the predicted thickness of the bilayer (Figure 7). To prove that the upper tectomer layer is rather secondary product, the sample firstly scanned in air was placed to liquid cell into buffer solution. Morphology of the pri-
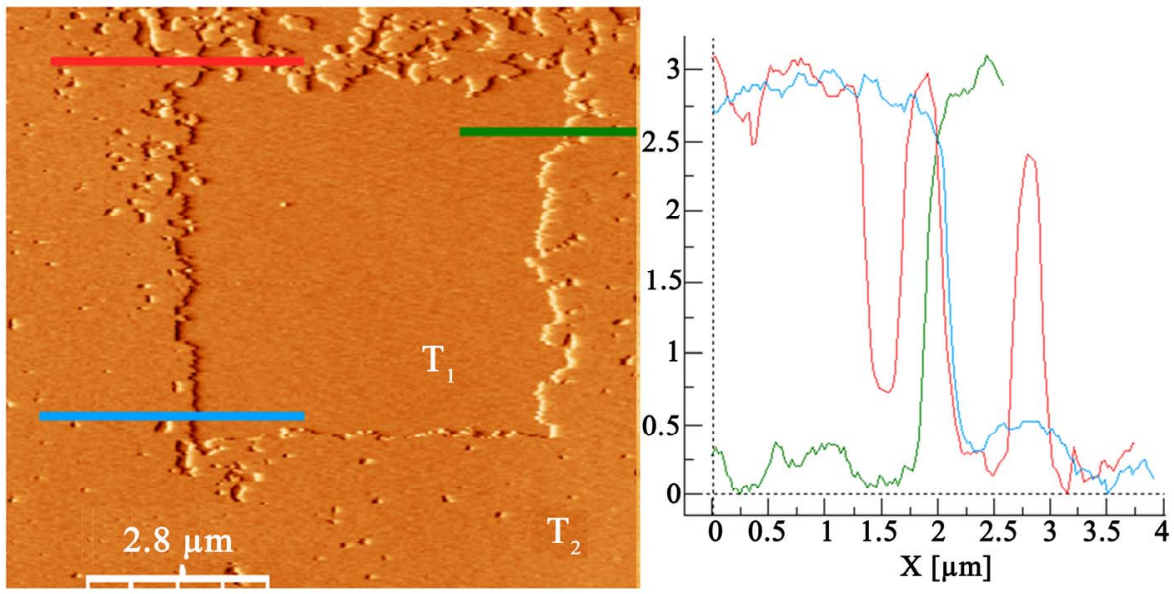

Figure 4. Assembling of $\left[\mathrm{Gly}_{7}-\mathrm{NHCH}_{2}-\right]_{3} \mathrm{CCH}_{3}$ on mica. The second layer has not been formed in the region of continuous scanning, whereas continued forming of it around this region took place. $T_{1}$, the first layer; $T_{2}$, the second layer. SFM contact mode in liquid cell. 


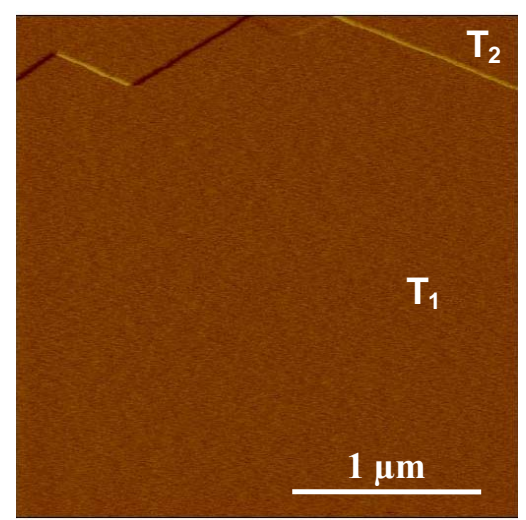

Figure 5. Peeling of $\left[\mathrm{Gly}_{7}-\mathrm{NHCH}_{2}-\right]_{3} \mathrm{CCH}_{3}$ upper layer; SFM contact mode in liquid cell. $T_{1}$, the first layer; $T_{2}$, the second layer.

mary layer remained practically unchanged, whereas islets of secondary layers were gradually dissolved (data not shown). Thus, simple washing seems to be a way to tectomer surface "purification" from secondary aggregates.

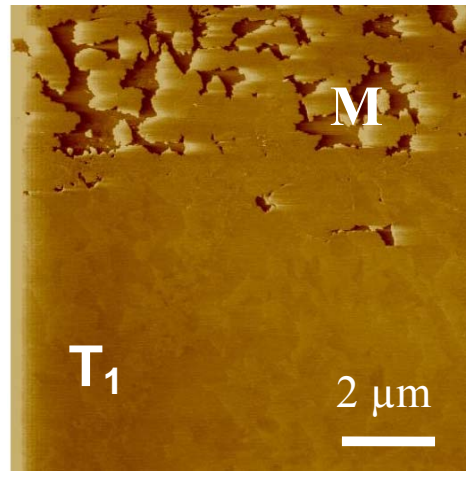

\section{Conclusion}

The assembling of three oligoglycine peptides, differing by antennary and hydrophobicity, has been studied on mica surface. All these peptides are capable of forming flat 2D crystalline layers on mica, where monomers are situated normally to the surface. The cases of lamellar disposition were not observed. Tetraantennary peptides form a monolayer whereas bi- and triantennary peptides having a hydrophobic motif in the molecule's central region form monolayer or bilayer. Interlayer adherence (between the hydrophobic motifs) is low; the upper layer can be removed with cantilever. The velocity of surface settlement increases by decrease of peptide antennary. Though tectomer assembly can also take place in solution, the assembly process proceeds two orders of magnitude more rapidly on mica surface, i.e. negatively charged surface plays an active role in promoting the assembly. We believe, oligoglycine tectomers can serve as a platform for nanodevices design and for smoothing and (due to amino groups) functionalization of rough

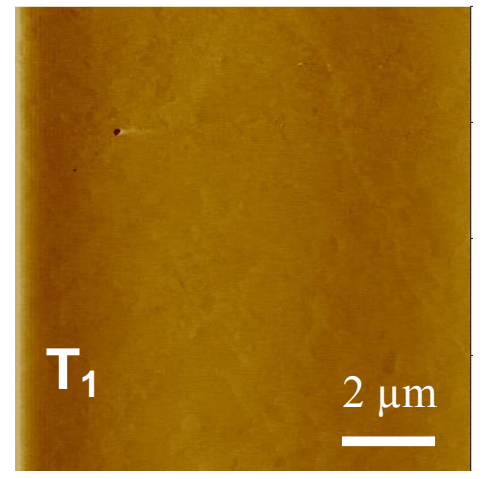

Figure 6. Growth dynamics of layer formed by $\left[\mathrm{Gly}_{4}-\mathrm{NH}\left(\mathrm{CH}_{2}\right)_{5}-\right]_{2}(0.1 \mathrm{mg} / \mathrm{ml})$ on mica surface, SFM contact mode in liquid cell. The first scan, islets are observed immediately. The second scan, defect-free layer is formed. $\mathrm{T}_{1}$, formed tectomer; $M$, yet uncovered mica regions.
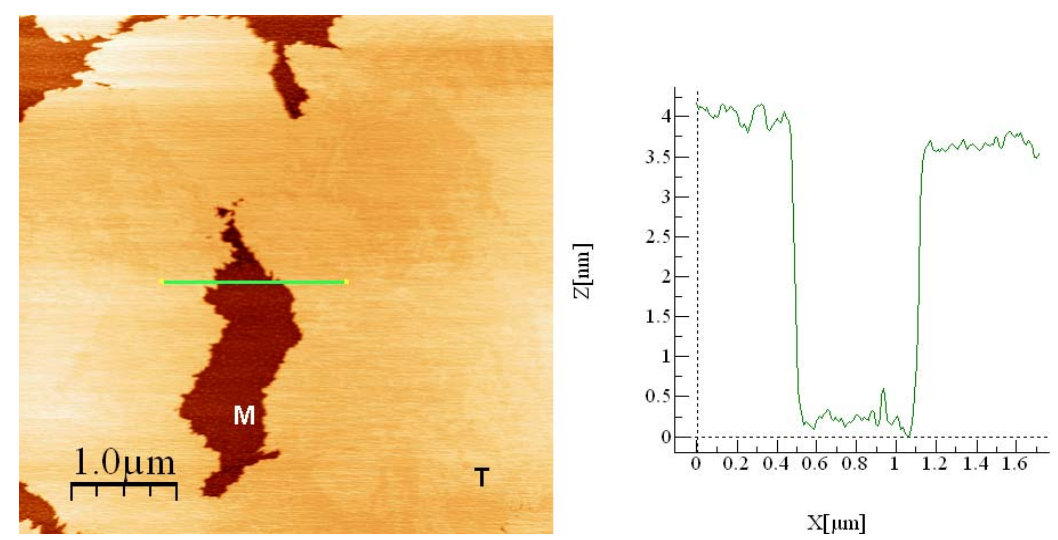

Figure 7. Tectomer layer formed by $\left[\mathrm{Gly}_{4}-\mathrm{NH}\left(\mathrm{CH}_{2}\right)_{5}-\right]_{2}(0.1 \mathrm{mg} / \mathrm{ml})$ on mica surface $(1 \mathrm{~min}$ incubation time on mica surface), SFM tapping mode in air. T, bilayer; $M$, uncovered mica. 
surfaces and seem to be a promising material for other nanotechnology applications [8].

\section{REFERENCES}

[1] J. -M. Lehn, "Supramolecular Chemistry: Concepts and perspectives," Wiley-VCH, Weinheim, 1995.

[2] V. Braach-Maksvytis and B. Raguse, "Highly Impermeable 'Soft' Self-Assembled Monolayers," Journal of American Chemical Society, Vol. 122, No. 39, 1995, pp 9544-9545. doi:10.1021/ja000917y

[3] C. H. Bamford, L. Brown, E.M. Cant, A. Elliott, W.E. Hanby and B. R. Malcolm, "Structure of Polyglycine," Nature, Vol. 176, No. 4478, 1955, pp 396. doi:10.1038/176396a0

[4] F. H. Crick and A. Rich, "Structure of Polyglycine II," Nature, Vol. 176, No. 4486, 1955, pp 780-781. doi:10.1038/176780a0

[5] T. Shimizu, M. Kogiso and M. Masuda, "Noncovalent Formation of Polyglycine II-Type Structure by Hexagonal Self-Assembly of Linear Polymolecular Chains," Journal of American Chemical Society, Vol. 119, No. 26, 1997, pp 6209-6210. doi:10.1021/ja970844r
[6] A. B. Tuzikov, A. A. Chinarev, A. S. Gambaryan, V. A. Oleinikov, D. V. Klinov, N. B. Matsko, V. A. Kadykov, M. A. Ermishov, I. V. Demin, V. V. Demin, P. D. Rye and N. V. Bovin, "Polyglycine II nanosheets: Supramolecular antivirals?" ChemBioChem, Vol. 4, No. 2-3, 2003, pp 147-154. doi:10.1002/cbic.200390025

[7] O. Gus'kova, P. Khalatur, A. Khokhlov, A. Chinarev, S. Tsygankova and N. Bovin, "Oligoglycine Surface Structures: Molecular Dynamics Simulation," Russian Journal of Bioorganic Chemistry, Vol. 36, No. 5, 2010, pp 574-580. doi:10.1134/S1068162010050043

[8] N. V. Bovin, A. A. Tuzikov and A. A. Chinarev, "Oligoglycines: Materials with unlimited potential for nanotechnologies," Nanotechnologies in Russia, Vol. 3, No. 5-6, 2008, pp 291-302. doi:10.1134/S1995078008050042

[9] A. A. Chinarev, A. B. Tuzikov, A. S. Gambaryan, M. N Matrosovich, A. Imberty and N. V. Bovin, "Tetravalent blockers for influenza virus hemagglutinin," In: Y. Inoue, Y. C. Lee and F. A. II Troy, Eds., Sialobiology and Other Novel Forms of Glycosylation, Gakushin Publishing Co., Osaka, 1999, pp. 135-143. 